\title{
Biodiversity of Actinomycetes from Heavy Metal Contaminated Technosols
}

\author{
Michaela Cimermanova ${ }^{1}$, Peter Pristas ${ }^{1,2}$ (D) and Maria Piknova ${ }^{1, *(D)}$ \\ 1 Institute of Biology and Ecology, P. J. Safarik University, Srobarova 2, 04154 Kosice, Slovakia; \\ michaela.cimermanova@student.upjs.sk (M.C.); peter.pristas@upjs.sk (P.P.) \\ 2 Centre of Biosciences, Institute of Animal Physiology, Slovak Academy of Sciences, Soltesovej 4-6, \\ 04001 Kosice, Slovakia \\ * Correspondence: maria.piknova@upjs.sk
}

Citation: Cimermanova, M.; Pristas,

P.; Piknova, M. Biodiversity of

Actinomycetes from Heavy Metal

Contaminated Technosols.

Microorganisms 2021, 9, 1635.

https://doi.org/10.3390/

microorganisms 9081635

Academic Editor: Volker Brozel

Received: 30 June 2021

Accepted: 28 July 2021

Published: 30 July 2021

Publisher's Note: MDPI stays neutral with regard to jurisdictional claims in published maps and institutional affiliations.

Copyright: (c) 2021 by the authors. Licensee MDPI, Basel, Switzerland. This article is an open access article distributed under the terms and conditions of the Creative Commons Attribution (CC BY) license (https:// creativecommons.org/licenses/by/ $4.0 /)$.

\begin{abstract}
Technosols are artificial soils generated by diverse human activities and frequently contain toxic substances resulting from industrial processes. Due to lack of nutrients and extreme physicochemical properties, they represent environments with limited bacterial colonization. Bacterial populations of technosols are dominated usually by Actinobacteria, including streptomycetes, known as a tremendous source of biotechnologically important molecules. In this study, the biodiversity of streptomycete-like isolates from several technosols, mainly mine soils and wastes (landfills and sludge) in Slovakia, was investigated. The combination of basic morphological and biochemical characterisations, including heavy metal resistance determination, and molecular approaches based on 16S rRNA gene analysis were used for the identification of the bacterial strains. From nine isolates of Actinobacteria collected from different habitats, one was found to represent a new species within the Crossiella genus. Eight other isolates were assigned to the genus Streptomyces, of which at least one could represent a new bacterial species. Some isolates showed high resistance to $\mathrm{Pb}, \mathrm{Zn}, \mathrm{Cu}$ or $\mathrm{Ni}$. The most tolerated metal was $\mathrm{Pb}$. The results obtained in this study indicate that technosols are a prospective source of new actinomycete species resistant to heavy metals what underlines their bioremediation potential.
\end{abstract}

Keywords: streptomyces; technosols; heavy metals; biodiversity

\section{Introduction}

Negative impacts on the environment by industry and urbanization represent worldwide problems as a majority of the human population lives near polluted areas. Moreover, contaminants pose a threat to remote areas through emission, leakage into the soil and water and due to accumulation in the food chain. Soils generated or radically transformed by human activities are called technosols or technogenic soils [1]. Lots of the technosols arise as a result of ore mining and ore processing. Such soils are characterized by a high concentration of toxic heavy metals.

Heavy metal ions in living organisms affect cell organelles and components such as the cell membrane, mitochondria, nucleus, DNA and enzymes, causing damage and conformational changes. Production of reactive oxygen species and oxidative stress have been shown to play a key role in the toxicity and carcinogenicity of heavy metals [2]. In addition to being toxic to most organisms in high concentrations, heavy metals are a problem for their stability and non-degradability [3]. Their availability to living organisms is affected especially by soil $\mathrm{pH}$, organic matter, and clay content. These factors affect the formation of the complexes, chelation and the immobilization of heavy metals. Soil acidification has the largest influence due to its strong effects on solubility of metals, which can lead to increased heavy metals bioavailability and reduced prokaryotic enzymatic activity [4,5]. Predominant groups of bacteria in heavy metal-contaminated soil are Proteobacteria, Acidobacteria, and Actinobacteria [6]. To survive adverse conditions, bacteria had to develop resistance 
mechanisms that involve the transformation of metals into less toxic and less mobile forms by reduction, oxidation, or methylation [7]. Another mechanism is the adsorption of metals on the cell surface, increased efflux pump activity, production of extracellular chelating agents (siderophores), intracellular sequestration and biomineralization [7]. Thanks to these mechanisms, bacteria are used in the remediation of contaminated environments by biological methods called bioremediation [8].

From heavy metal-contaminated areas, several streptomyces strains have been isolated [7]. Genus Streptomyces is the most numerous and most common genus of Actinobacteria phylum. Today, this genus consists of almost 700 validly described species [9] and includes Gram-positive, aerobic, filamentous bacteria with a high content of guanine and cytosine in DNA (69-78 mol\%). Actinobacteria, especially streptomycetes, are considered the key microorganisms participating in decomposition and recycling of organic matter in soils due to their efficient enzymatic systems. They are known to produce a large number of enzymes having multifaceted industrial applications [10]. Streptomycetes are also important producers of secondary metabolites, producing more than one-third of commercially available antibiotics. Other effects of their metabolites include antimicrobial, antifungal, antiparasitic, antitumor and immunosuppressive activities [10].

At present, the demand for new active substances is growing rapidly, mainly due to the increasing occurrence of resistant pathogens, but also for other needs of medicine, agriculture, and industry. To increase the possibility of the discovery of new species and new bioactive metabolites, research is currently focused on unexplored and harsh environments [11]. Adverse abiotic conditions are thought to select microorganisms capable of adapting to and thus expressing new chemical compounds [12]. The benefit of researching bacteria from contaminated areas lies not only in their use in decontamination and restoration of polluted environments but is also important for the discovery of new chemical structures and new microbial species.

In our work we focused on the isolation and identification of variability of streptomycetes from several technosols in Slovakia. Metal pollution in Slovakia is mainly due to former mining activities, ore processing and industrial plants. In 2019, 103 mining waste repositories were operated, of which 83 were dumps and 20 mining sludges. There are 338 closed and abandoned mining waste repositories registered in the Slovak Republic, of which 28 pose a risk to health and the environment [13]. The most contaminated areas are situated in Central Spiš (Rudňany, Krompachy, and Slovinky municipalities), where excessive contamination of mercury, copper, zinc, arsenic, cadmium, and lead is observed. Other highly contaminated areas are in Jelšava and Hnúšt'a municipalities $(\mathrm{Hg}, \mathrm{Mg}, \mathrm{Cd}$, $\mathrm{Pb}$ ), Žiar nad Hronom (F, Hg, As) and Dolná Orava (Istebné-Cr, Mn) [14]. In present work we studied streptomycetes from technosol samples from metal-contaminated areas in Slovinky, Gelnica, and Hnúšt'a.

\section{Materials and Methods}

\subsection{Isolation and Characterization of Isolates}

For streptomycete isolation, samples from Slovinky, Gelnica, and Hnúšt'a mining wastes were used. All sampling areas were formed by remnants from mining activities. Two tailing ponds in Slovinky originated as a result of mining and processing of copper ores. The tailings are near-neutral or slightly alkaline $(\mathrm{pH}=7.2-8.8)$ [15]. Sediments contain high concentrations of $\mathrm{Cu}, \mathrm{As}, \mathrm{Sb}, \mathrm{Pb}, \mathrm{Zn}$, and $\mathrm{Ba}$, which are relatively tightly bound in minerals and are characterized by low mobility, mainly due to the slightly alkaline nature of the sediments [16]. Near Gelnica town there are repositories of waste, especially after silver and copper mining. The surrounding soils are characterized by contamination with heavy metals, especially As, $\mathrm{Hg}$ and $\mathrm{Cu}$. The content of $\mathrm{Zn}$ and $\mathrm{Pb}$ also exceeded the limit values [17]. The heap near the town of Hnúšt' a was formed as a result of magnesite and talc mining. An increased content of heavy metals, especially $\mathrm{As}, \mathrm{Pb}, \mathrm{Zn}$ and $\mathrm{Co}$, was noted even in the surrounding soils [18]. 
Substrate samples from sludge ponds and heaps were taken by random sampling to a depth of $10 \mathrm{~cm}$ from three locations: Slovinky (two sampling sites, November 2016 [19]), Gelnica (three sampling sites, July 2017) and Hnúšt'a (one sampling site, October 2017). Substrate samples were kept at $4{ }^{\circ} \mathrm{C}$ and transported to the laboratory as soon as possible. From each technosol, $1 \mathrm{~g}$ of sample was shaken in $10 \mathrm{~mL}$ of Phosphate Buffered Saline with Tween 20 (PBS-T, Sigma-Aldrich, St. Louis, MO, USA) at room temperature (RT), $130 \mathrm{rpm}$ for $30 \mathrm{~min}$ and $100 \mu \mathrm{L}$ of appropriate dilutions were inoculated on Benedict's modification of the Lindenbein selective medium for streptomycetes [20]. After incubation at RT for 7 days, colonies with streptomyces-like characteristic were subcultured on Tryptic Soy Agar plates (TSA, Sigma-Aldrich, St. Louis, MO, USA). The isolates were stored as spores' suspensions in $20 \%$ glycerol at $-70{ }^{\circ} \mathrm{C}$ [21].

Isolates were morphologically characterized by determining the production of diffuse pigments and the color of aerial and substrate mycelium on TSA medium and then classified into a color class [22]. Selected isolates were tested for enzyme activities (proteolytic, lipolytic, amylolytic and cellulolytic) using TSA medium supplemented with milk powder $(1 \% w / v)$, glycerol tributyrate $(1 \% v / v)$, Starch azure $(0.65 \% w / v)$ or carboxymethyl cellulose $(2.6 \% w / v)$ [23-25]. Growth at different temperatures (RT and $37^{\circ} \mathrm{C}$ ) was tested on TSA medium and growth at different $\mathrm{pH}$ (5 and 7) was tested on TSA medium with $50 \mathrm{mM}$ TRIS (tris(hydroxymethyl)aminomethane) $(0.6 \% v / v)$, adjusted with $\mathrm{NaOH}$ solution.

\subsection{Molecular Identification and Diversity Estimation}

For DNA isolation, spores (single loop) were inoculated into $50 \mathrm{~mL}$ of Tryptic Soy Broth (TSB, Sigma-Aldrich, St. Louis, MO, USA) medium (3 g per $100 \mathrm{~mL}$ of TSB) and cultivated aerobically at RT for 2 days at $150 \mathrm{rpm}$. Total DNA was isolated as described by Nybo et al. with some modifications [26]. Gene for $16 \mathrm{~S}$ rRNA was amplified by polymerase chain reaction (PCR) using universal bacterial primers fD1 (5'-AGAGTTTGATCCTGGCTCAG-3') and rP2 (5'-ACGGCTACCTTGTTACGACTT-3') [27] in a C1000 Thermal Cycler (Bio-Rad Laboratories, Richmond, VA, USA). PCR reactions were performed according to Vandžurová et al. with minor modifications; specifically, we used 25 pmol of each primer (Jena Bioscience, Jena, Germany), denaturation was performed at $95^{\circ} \mathrm{C}$ and primer annealing at $54{ }^{\circ} \mathrm{C}$ [28]. Amplified fragments were analysed by the restriction fragment length polymorphism (RFLP) method using HaeIII, HhaI, AluI or MspI (Thermo Fisher Scientific, Waltham, MA, USA) restriction endonucleases according to the manufacturer's instructions. The restriction fragments were separated by electrophoresis in $1.5 \%(w / v)$ agarose gel.

DNA sequencing of selected $16 \mathrm{~S}$ rRNA amplicons was performed by Eurofins Genomics GATC Services (Eurofins Genomics, Ebersberg, Germany), and the obtained sequences were assembled using MEGA software [29] and compared against the NCBI database using BLASTn algorithm [30]. Accession numbers of sequences deposited to GenBank are MZ438589-MZ438597 for isolates C1, GS1, H6, J1, J2, S2, S7, SL2, and SLA, respectively.

To analyse the phylogenetic relationships among isolates based on 16S rRNA gene sequences, sequences of the most related species were downloaded from the GenBank database, aligned using ClustalW algorithm and phylogenetic tree (Figure 1) was constructed using the neighbor-joining method with 1000 bootstrap replicates using MEGA version X [29]. The species that were heterotypic synonyms [31] were not included in the tree.

\subsection{Analysis of Heavy Metal Resistance}

Determination of resistance to heavy metals of selected isolates was performed by determining the minimum inhibitory concentration (MIC) against zinc $\left(\mathrm{ZnCl}_{2}\right)$, nickel $\left(\mathrm{NiCl}_{2}\right)$, copper $\left(\mathrm{CuCl}_{2}\right)$ and lead $\left(\mathrm{Pb}\left(\mathrm{CH}_{3} \mathrm{COO}\right)_{2}\right)$ on modified Duxbury agar [32] supplemented with individual metals. Tested concentrations for $\mathrm{Zn}, \mathrm{Ni}$ and $\mathrm{Cu}$ were $2 ; 4 ; 8 ; 64 ; 100 ; 150$; 250; $300 \mathrm{mg} / \mathrm{L}$, and for $\mathrm{Pb} 8 ; 64 ; 125 ; 250 ; 300 ; 500 ; 700 ; 1000 ; 1500 \mathrm{mg} / \mathrm{L}$. Inoculated plates were incubated for 7 days at RT. MIC was determined as the lowest concentration with no visible bacterial growth [32]. In order to evaluate the effect of the medium on the growth of 
isolates in the presence of metal, we tested the growth of isolates at a metal concentration of $64 \mathrm{mg} / \mathrm{L}$ on modified Duxbury agar and on complex TSA medium.

\section{Results}

\subsection{Isolation and Characterization of Isolates}

A total of 37 isolates were obtained. Isolated actinomycetes showed similar morphological characteristics and a low rate of melanoid pigment production after 7 days of incubation at RT. Almost all isolates belonged to a white aerial mass color series. The colors of substrate mycelium were mostly beige, yellowish brown to orange. Due to high morphological similarity and low variability of RFLP cleavage profiles (data not shown), we selected for further analysis only 9 different isolates so that each sampling site was represented. Enzyme production was mostly positive. Isolate S7, which hydrolyzed only starch, showed the lowest activity. Overall, we observed low cellulase production, only isolate S2 was characterized by a positive reaction with ratio of the diameter of the clear zone to colony diameter 1.19. Lower $\mathrm{pH}$ did not influence the growth of isolates, whereas elevated temperature $\left(37^{\circ} \mathrm{C}\right)$ inhibited the growth of almost half of them. The characteristics of selected isolates are shown in Table 1.

Table 1. Morphological characteristics of selected isolates, enzyme production and growth characteristic.

\begin{tabular}{|c|c|c|c|c|c|c|c|c|c|c|c|}
\hline Sampling Site & Isolate & Substrate Mycelium & Aerial Mycelium & Pigment & Protease & Lipase & Amylase & Cellulase & $37^{\circ} \mathrm{C}$ & pH 5 & $\mathrm{pH} 7$ \\
\hline \multirow{5}{*}{ Gelnica } & $\mathrm{C} 1$ & $\mathrm{O}$ & W & - & + & \pm & + & \pm & + & + & + \\
\hline & GS1 & $\mathrm{B}$ & W & - & + & - & + & \pm & - & + & + \\
\hline & H6 & $\mathrm{B}$ & W & $\mathrm{Br}$ & + & + & + & \pm & - & + & + \\
\hline & $\mathrm{J} 1$ & B & $\mathrm{W}$ & - & + & + & + & - & + & + & + \\
\hline & $\mathrm{J} 2$ & B & W & - & + & + & + & - & + & + & + \\
\hline \multirow{2}{*}{ Hnúšt’a } & $\mathrm{S} 2$ & B & $\mathrm{W}$ & - & - & \pm & - & + & - & + & + \\
\hline & S7 & $\mathrm{O}$ & $\mathrm{C}$ & $\mathrm{Br}$ & - & - & + & - & - & + & + \\
\hline \multirow{2}{*}{ Slovinky } & SL2 & B & $\mathrm{W}$ & - & + & \pm & + & \pm & + & + & + \\
\hline & SLA & $\mathrm{Y}-\mathrm{Br}$ & W & - & + & \pm & + & \pm & + & + & + \\
\hline
\end{tabular}

B: beige, Br: brown, C: colorless, O: orange, W: white, Y-Br: yellow-brown, "+" positive reaction/growth, " \pm " slightly positive reaction, "-" negative reaction/no pigment/no growth.

\subsection{Identification of Isolates}

The $16 \mathrm{~S}$ rRNA sequences of all isolates obtained showed a length of around $1300 \mathrm{bp}$. BLAST analysis clustered our isolates to six operational taxonomic units (OTUs) at the 99\% of identity. $99 \%$ sequence identity of full-length sequences is considered an optimal threshold value for species delineation $[33,34]$. Many assigned species were reclassified by the authors Rong et al., Kim et al. and Liu et al. as heterotypic synonyms [31,35-38]. Specifically, Streptomyces coelicolor, limosus, sampsonii and felleus are a later heterotypic synonym of S. albidoflavus [35], S. praecox is later heterotypic synonym of S. anulatus [31], S. albovinaceus, griseinus and mediolani is S. globisporus [35], the correct name for S. caviscabies, baarnensis, acrimycini, fimicarius and flavofuscus is S. griseus [34,36], and for S. fulvissimus and alboviridis the correct name is S. microflavus [34,37]. In the phylogenetic tree (Figure 1), we did not include later heterotypic synonyms, except for $S$. coelicolor (a later synonym of S. albidoflavus) and S. flavofuscus (a later synonym of S. griseus) because S. albidoflavus and S. griseus had slightly lower sequenced identity $(99.92 \%)$ than their synonyms $(100 \%)$ to our isolates.

The diversity of sampling sites consisted of five OTUs of streptomycetes and one Crossiella sp. (Figure 1). If we do not include heterotypic synonyms but only correct names [9] we can say that the isolate C1 and SLA had $100 \%$ sequence identity of the $16 \mathrm{~S}$ rRNA gene with six different species, namely S. rubiginosohelvolus, S. globisporus, S. parvus, S. pluricolorescens, S. badius and S. sindenensis. Isolate GS1 and SL2 had 100\% identity to S. microflavus. Isolate H6 showed $100 \%$ identity to four species, namely S. pratensis, S. griseus, S. anulatus and S. cyaneofuscatus. Isolate S7 had $99.92 \%$ identity to the same species as isolate $\mathrm{H6}$ but it forms a separate, well supported, branch in the phylogenetic tree indicating that it could represent a novel species. Isolates J1 and J2 had $100 \%$ identity with three species (S. albidoflavus, S. resistomycificus and S. griseochromogenes). S2 isolate was 
assigned to Crossiella cryophila with 16S rRNA gene sequence identity $99.06 \%$. Due to its location in a phylogenetic tree, it may also represent a novel species.

Despite the fact that isolates C1 and SLA as well as GS1 and SL2 shared identical 16S rRNA gene sequences, they probably represent different bacterial species based on their different characteristics (Table 1). Isolates J1 and J2 are more likely to be identical as they were isolated from the same sampling site and share the same characteristics. They differ significantly only in the degree of heavy metal resistance levels.

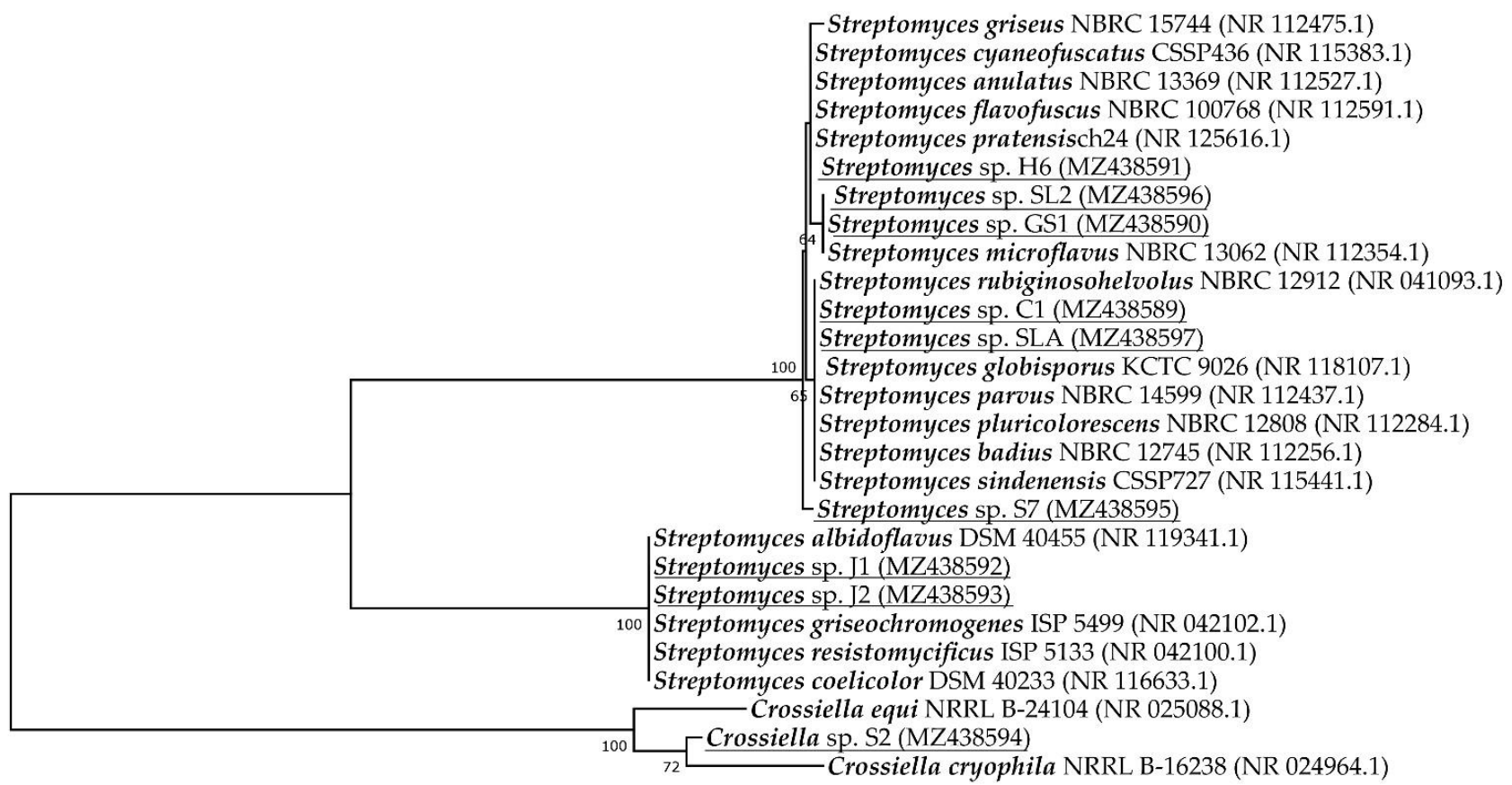

0.01

Figure 1. The phylogenetic tree based on the $16 \mathrm{~S}$ rRNA gene sequences. The evolutionary history was inferred using the neighbor-joining method [39]. The optimal tree with the sum of branch length $=0.13126272$ is shown. The percentage of replicate trees in which the associated taxa clustered together in the bootstrap test (1000 replicates) are shown next to the branches [40]. The tree is drawn to scale, with branch lengths in the same units as those of the evolutionary distances used to infer the phylogenetic tree. The evolutionary distances were computed using the Kimura 2-parameter method [41] and are in units of the number of base substitutions per site. The analysis involved 27 nucleotide sequences, the isolates included in this study are underlined. All ambiguous positions were removed for each sequence pair (pairwise deletion option). There was a total of 1274 positions in the final dataset. Evolutionary analyses were conducted in MEGA X [29].

\subsection{Heavy Metal Resistance}

Heavy metal resistance of selected isolates against $\mathrm{Cu}, \mathrm{Ni}, \mathrm{Pb}$ and $\mathrm{Zn}$ on modified Duxbury medium is summarized in Table 2 . We noted differences in heavy metal toxicity between isolates even from the same sampling point. All isolates were tolerant to a relatively high concentration of lead in medium (125-1000 mg/L), and the highest MIC for lead was $1000 \mathrm{mg} / \mathrm{L}$ in $33 \%$ of isolates. According to Duxbury, bacteria can be referred as metal tolerant when can grow in the presence of metal concentration higher than $110 \mathrm{mg} / \mathrm{L}$ for $\mathrm{Zn}, 85 \mathrm{mg} / \mathrm{L}$ for $\mathrm{Cu}$ and $100 \mathrm{mg} / \mathrm{L}$ for Ni [42]; $44 \%$ of isolates were tolerant to zinc and copper and 33\% to nickel. The highest MIC for $\mathrm{Zn}, \mathrm{Cu}$ and Ni was $300 \mathrm{mg} / \mathrm{L}$. The most tolerated metal for our isolates was $\mathrm{Pb}$ and the most toxic was $\mathrm{Cu}$. The growth of isolates in the presence of metals was more intense on complex TSA medium compared to modified Duxbury agar (Figure 2). Compared to the control (metal-free medium), the percentage growth of isolates on TSA medium was almost $100 \%$ for $\mathrm{Pb}, \mathrm{Cu}$ and $\mathrm{Ni}$ and $40 \%$ for $\mathrm{Zn}$. On Duxbury agar, isolates growth was $80 \%$ for $\mathrm{Pb}$ and only about $5 \%$ for $\mathrm{Zn}, \mathrm{Cu}$ and $\mathrm{Ni}$. 
Table 2. Minimal inhibitory concentration (MIC) of isolates on modified Duxbury agar.

\begin{tabular}{cccccc}
\hline \multirow{2}{*}{ Sampling Site } & Isolate & \multicolumn{4}{c}{ MIC [mg/L] } \\
\cline { 3 - 6 } & & $\mathbf{C u}$ & $\mathbf{N i}$ & $\mathbf{P b}$ & $\mathbf{Z n}$ \\
\hline \multirow{3}{*}{ Gelnica } & $\mathrm{C} 1$ & 4 & 8 & 300 & 250 \\
& $\mathrm{GS} 1$ & 300 & 300 & 1000 & 300 \\
& $\mathrm{H} 6$ & 300 & 8 & 1000 & 300 \\
& $\mathrm{~J} 1$ & 2 & 100 & 300 & 100 \\
& $\mathrm{~J} 2$ & 2 & 8 & 300 & 8 \\
\hline \multirow{2}{*}{ Hnúš́ta } & $\mathrm{S} 2$ & 64 & 100 & 250 & 100 \\
& $\mathrm{~S} 7$ & 300 & 150 & 125 & 64 \\
\hline \multirow{2}{*}{ Slovinky } & $\mathrm{SL} 2$ & 300 & 250 & 1000 & 300 \\
& $\mathrm{SLA}$ & 4 & 8 & 300 & 64 \\
\hline
\end{tabular}

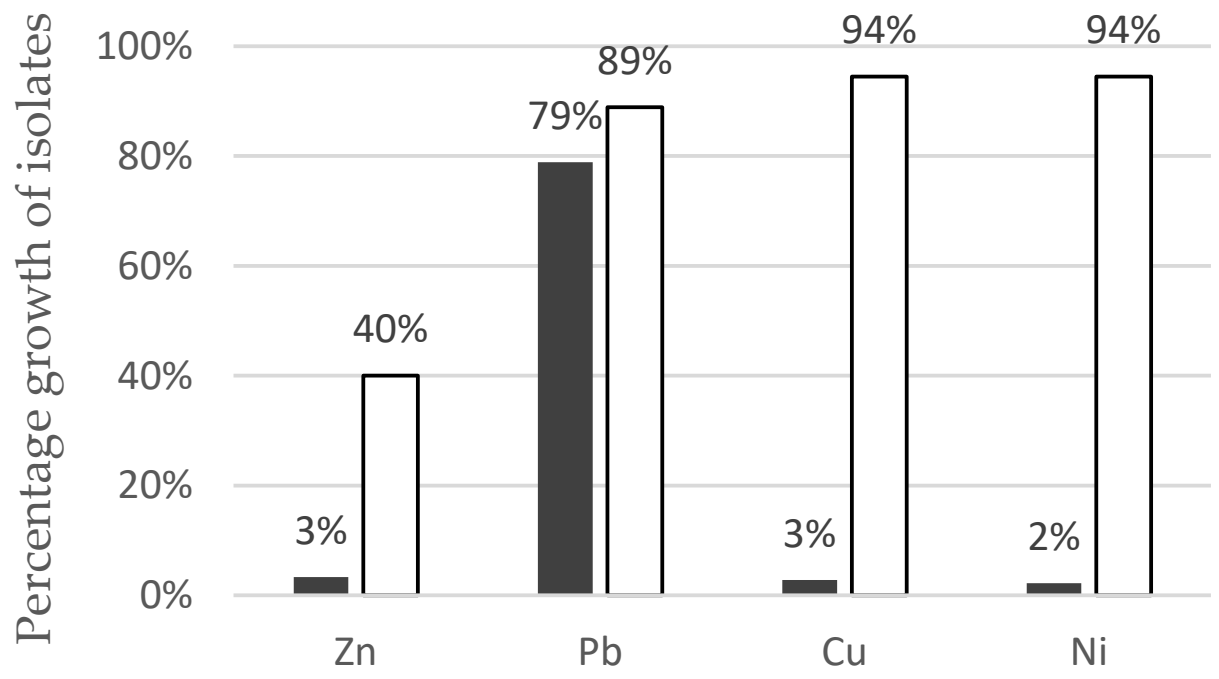

\section{on modified Duxbury agar $\quad \square$ on TSA medium}

Figure 2. Percentage growth of isolates on modified Duxbury agar medium and Tryptic Soy Agar (TSA) medium with $\mathrm{Zn}, \mathrm{Pb}, \mathrm{Cu}$ and $\mathrm{Ni}$ at concentration $64 \mathrm{mg} / \mathrm{L}$ against control (media without metal).

\section{Discussion}

The aim of this work was to characterize the isolates from heavy metal-contaminated technosols from several mining and heavy metal industry waste disposal sites in Slovakia (near Gelnica, Slovinky and Hnúšt'a). We characterized nine species of which eight belonged to Streptomyces genus (closely related to S. rubiginosohelvolus, S. globisporus, S. parvus, S. pluricolorescens, S. badius, S. sindenensis, S. microflavus, S. pratensis, S. griseus, S. anulatus, S. cyaneofuscatus, S. albidoflavus, S. resistomycificus and S. griseochromogenes). The last isolate was found to belong to the Crossiella genus with the highest similarity to Crossiella cryophila. Streptomyces spp. have already been characterized from technosols from heavy metal industry waste disposal sites in Slovakia, including those in Sered' and Žiar nad Hronom [43]. The technosols from a nickel sludge disposal site near Sered' are characterized by strongly alkaline $\mathrm{pH}$ and high content of heavy metals, especially $\mathrm{Cr}$ and $\mathrm{Ni}$ [44,45]. Actinobacteria were found to be a dominant phylum of cultivable bacteria with Arthrobacter as a dominant genus. S. variabilis was identified as a single representative of Streptomyces genus [43]. In earlier study, Actinomyces spp. were also isolated from farmland near waste disposal site of nickel smelter near Sered' and among other isolates two Streptomyces spp. closely related to S. collinus and S. exfoliatus were isolated [46]. From brown mud disposal site from aluminum production near Žiar nad Hronom, two streptomycete species closely related to 
S. wuyuanensis and S. malaysiensis (based on $16 \mathrm{~S}$ rRNA sequences) were isolated [43,47]. Site is characterized by elevated concentrations of heavy metals like $\mathrm{As}, \mathrm{Pb}, \mathrm{Hg}$ and $\mathrm{Cr}$. Streptomyces K11 isolate showed resistance to zinc up to $150 \mathrm{mM}$ and high zinc bioaccumulation capacity [47].

To date, several heavy metal-resistant streptomycetes have been isolated from various contaminated areas [7]. Álvarez et al. analysed the spread of resistance to heavy metals in the phylogeny of streptomycetes based on bibliographic data and sequence availability for the 16S rRNA gene, confirming the broad spread of resistance in different branches [7]. In his work, they summarized heavy metal resistant strains of streptomycetes from accessible bibliographies. In Table 3, we depict novel heavy metal-resistant species which were isolated from metal-contaminated areas. The literature review (Table S1: List of strains from heavy metal-contaminated areas) suggests that many Streptomyces species with unique characteristics were isolated from soils of metal-contaminated areas [32,47-74]. For example, Schmidt et al. isolated streptomycetes highly resistant to nickel from a polluted site at the former uranium mine [57]. Similarly, El Baz et al. isolated from various abandoned mining areas located around Marrakech heavy metal-resistant Streptomyces sp., capable of accumulating lead [32]. Isolate Streptomyces sp. Z38 from rhizosphere soil contaminated with pesticides and heavy metals characterized as S. griseorubens was able to grow abundantly in the presence of $250 \mathrm{mg} / \mathrm{L}$ of $\mathrm{Cr}(\mathrm{IV})$ and produced plant growthpromoting metabolites $[63,64]$. Isolate Streptomyces sp. H-KF8 with antimicrobial activity against $S$. aureus, L. monocytogenes, and E. coli was isolated from marine sediments with the natural occurrence of heavy metals due to volcanic activity. It was also characterized by the tolerance to various heavy metals, such as $\mathrm{Cu}, \mathrm{Co}, \mathrm{Hg}, \mathrm{Cr}, \mathrm{Ni}$ and $\mathrm{Te}$, with 49 genes likely involved in heavy metal resistance $[65,66]$. The high resistance to various heavy metals and the ability of bioaccumulation and biosorption indicates the possibility of use of isolates in the bioremediation of contaminated areas [32,75]. Moreover, adaptation to such adverse conditions may cause the production of new secondary metabolites [12]. Adverse environments are, therefore, the focus of interest in the search for new species of Actinobacteria, antibiotics and other useful substances for medicine and the economy [76].

Table 3. Novel Streptomyces species isolated from heavy metal contaminated areas from reviewed literature.

\begin{tabular}{|c|c|c|c|c|c|}
\hline Isolate & Strain & Acc. Number & Place of Isolation & Country & Reference \\
\hline S. cadmiisoli & ZFG47 & NR_171522.1 & $\begin{array}{l}\text { soil in a cadmium-contaminated } \\
\text { area in Xiangtan City }\end{array}$ & Hunan Province, China & {$[71]$} \\
\hline S. cyaneochromogenes & $\mathrm{MK}-45$ & NR_170501.1 & manganese-contaminated area & Xiangtan, China & {$[68]$} \\
\hline S. manganisoli & MK 44 & KY911452.1 & $\begin{array}{c}\text { manganese-polluted soil, Xiangtan } \\
\text { Manganese Mine }\end{array}$ & South Central China & {$[70]$} \\
\hline S. plumbiresistens & CCNWHX 13-160 & EU526954 & lead-polluted soil, Gansu province & Northwest China & {$[60]$} \\
\hline S. sporoverrucosus & dwc-3 & КС508633.1 & $\begin{array}{l}\text { disposal site for (ultra-)low } \\
\text { uraniferous radioactive waste }\end{array}$ & Southwest China & [67] \\
\hline S. xiangtanensis & LUSFXJ & NR_164877.1 & $\begin{array}{c}\text { manganese-polluted soil, Xiangtan } \\
\text { Manganese Mine }\end{array}$ & South Central China & {$[72]$} \\
\hline S. zinciresistens & CCNWNQ 0016 & GU225938 & $\begin{array}{l}\text { zinc and copper mine, Shaanxi } \\
\text { province }\end{array}$ & Northwest China & {$[61]$} \\
\hline
\end{tabular}

This work, like many previous ones, points to low variability within the 16S rRNA gene for species identification of streptomycetes. However, it allows us to estimate groups of closely related species and to classify isolates into the clades or OTUs [77]. Labeda et al. [77] studied almost all described species of the Streptomycetaceae family (615 species at the time) based on the sequences of the 16S rRNA gene. They found that this family contained 130 statistically based clades as well as many unsupported and single member clusters. Our isolates were related mainly to species not described by Labeda et al. or to clade 112 (S. albidoflavus). El Baz et al. [32] isolated also some species related to clade 112. Other species from reviewed literature were mainly from OTUs not reported 
by Labeda et al. or from clade 103 (S. tendae). The observed high species variability of streptomycete populations from heavy metal-contaminated areas indicates that different autochthonous species are able to adapt to high concentrations of metals. It is well known that taxonomic characterization of Streptomyces is complicated and challenging because species sharing identical small subunit rRNA sequence can exhibit clearly different properties and secondary metabolism, as reported e.g., by Antony-Babu et al. [78]. Therefore, additional phylogenetic markers, such as MLSA analysis of housekeeping genes, with discriminatory power better than 16S rRNA gene, are essential to evaluate the evolutionary relationships among closely related Streptomyces species [10,31]. This underlines the importance of examining the properties of specific strains, in order to discover their true potential.

The identification of Crossiella sp. in heavy metal-contaminated technosols is quite surprising. The type strain of the genus, Crossiella cryophila was isolated from pristine soil from Shosenkyo, Yamanashi Prefecture, Japan and to date, two species of the genus, C. cryophila and C. equi have been described [9]. So far, there have only been a few records of this species in the literature. Our isolate, despite related to C. cryophila, showed significant heavy metal resistance and differed from the type strain [79] in several biochemical properties. Due to its position in the phylogenetic tree, it may represent a new species of this small genus.

Regarding the resistance of our isolates to heavy metals, most of our isolates showed high resistance to selected heavy metals on modified Duxbury agar. Maximum concentrations at which our isolates were able to grow were $250 \mathrm{mg} / \mathrm{L}$ (3.82 mM) for Zn, $250 \mathrm{mg} / \mathrm{L}$ (3.93 mM) for $\mathrm{Cu}, 250 \mathrm{mg} / \mathrm{L}(4.26 \mathrm{mM})$ for $\mathrm{Ni}$, and $700 \mathrm{mg} / \mathrm{L}$ (3.38 mM) for Pb. Most resistant isolates were GS1 and SL2, closely related to S. microflavus. However, comparing resistance with other available literature is relatively difficult as the authors use different solid and liquid media which have, as confirmed also in our work, a significant impact on the bioavailability of metals for microorganisms $[32,56]$. We can say that the composition of the medium has a significant effect on the toxicity of metals and Duxbury agar affects the bioavailability of metals less than TSA medium (Figure 2), as also stated by El Baz et al. [32]. Lead was one of the most tolerated heavy metals in our isolates and similar results were obtained by El Baz et al. [32]. More important than the resistance itself is the application of isolates for bioremediation of polluted areas. Sometimes even strains with lower tolerance to heavy metals can be better metal adsorbents than highly resistant ones. This was observed e.g., for lead tolerance in S. viridochromogenes, when the most adsorbing strain was at the same time the most sensitive one to this metal [52]. The usability of isolates in bioremediation and their biosynthetic potential will be the subject of further study.

\section{Conclusions}

Extreme environments, including metal-contaminated areas, are generally underexplored. However, it has become clear that they present a promising source of novel microorganisms with the genus Streptomyces being undoubtedly the most prominent producer of putative new bioactive molecules and with a bioremediation potential. Our study explores the diversity of streptomycete-like isolates with high metal resistance from heavy metal-contaminated technosols in Slovakia. We identified nine isolates of which eight belonged to Streptomyces genus, closely related to several Streptomyces species. One isolate belonged to the Crossiella genus. Some of our isolates were highly resistant to metals with the highest MIC for Pb $1000 \mathrm{mg} / \mathrm{L}$ and for $\mathrm{Zn}, \mathrm{Cu}$ and Ni $300 \mathrm{mg} / \mathrm{L}$. Some isolates exhibited notable enzymatic activity, mainly proteolytic and amylolytic. The results obtained indicate that at least two of our isolates could be representatives of new bacterial species within Streptomyces (isolate S7) and Crossiella genera (isolate S2).

Supplementary Materials: The following are available online at https://www.mdpi.com/article/10 .3390 / microorganisms 9081635 / s1, Table S1: List of streptomycete strains from heavy metal contaminated areas. 
Author Contributions: M.C.: methodology, investigation, writing-original draft preparation. M.P.: conceptualization, data curation, writing - review and editing, funding acquisition. P.P.: Conceptualization, writing - review and editing, supervision, project administration, funding acquisition. All authors have read and agreed to the published version of the manuscript.

Funding: This research was funded by VEGA Grant Agency (grant number 1/0779/21) and APVV Grant Agency (grant number SK-PL-18-0012). MC acknowledges the support from VVGS-pf-20211766 grant.

Institutional Review Board Statement: Not applicable.

Informed Consent Statement: Not applicable.

Data Availability Statement: All 16S rRNA data obtained through this study were deposited to the GenBank database.

Conflicts of Interest: The authors declare no conflict of interest.

\section{References}

1. Uzarowicz, Ł.; Charzyński, P.; Greinert, A.; Hulisz, P.; Kabała, C.; Kusza, G.; Kwasowski, W.; Pędziwiatr, A. Studies of Technogenic Soils in Poland: Past, Present, and Future Perspectives. Soil Sci. Ann. 2020, 71, 281-299. [CrossRef]

2. Tchounwou, P.B.; Yedjou, C.G.; Patlolla, A.K.; Sutton, D.J. Heavy Metal Toxicity and the Environment. Exp. Suppl. 2012, 101, 133-164. [CrossRef]

3. Ahluwalia, S.S.; Goyal, D. Microbial and Plant Derived Biomass for Removal of Heavy Metals from Wastewater. Bioresour. Technol. 2007, 98, 2243-2257. [CrossRef] [PubMed]

4. Giller, K.E.; Witter, E.; Mcgrath, S.P. Toxicity of Heavy Metals to Microorganisms and Microbial Processes in Agricultural Soils: A Review. Soil Biol. Biochem. 1998, 30, 1389-1414. [CrossRef]

5. Torsvik, V.; Øvreås, L. Chapter 2 Microbial Diversity, Life Strategies, and Adaptation to Life in Extreme Soils; Dion, P., Nautiyal, C.S., Eds.; Springer: Berlin/Heidelberg, Germany, 2008; Volume 13.

6. Hur, M.; Park, S.-J. Identification of Microbial Profiles in Heavy-Metal-Contaminated Soil from Full-Length 16S RRNA Reads Sequenced by a PacBio System. Microorganisms 2019, 7, 357. [CrossRef] [PubMed]

7. Álvarez, A.; Catalano, S.A.; Amoroso, M.J. Heavy Metal Resistant Strains Are Widespread along Streptomyces Phylogeny. Mol. Phylogenet. 2013, 66, 1083-1088. [CrossRef] [PubMed]

8. Frankovská, J.; Slaninka, I.; Kordík, J.; Jurkovič, L'.; Greif, V.; Šottník, P.; Dananaj, I.; Mikita, S.; Dercová, K.; Jánová, V. Atlas Sanačných Metód Environmentálnych Zát'aží; Štátny Geologický Ústav Dionýza Štúra: Bratislava, Slovakia, 2010.

9. Parte, A.C.; Sardà Carbasse, J.; Meier-Kolthoff, J.P.; Reimer, L.C.; Göker, M. List of Prokaryotic Names with Standing in Nomenclature (LPSN) Moves to the DSMZ. Int. J. Syst. Evol. Microbiol. 2020, 70, 5607-5612. [CrossRef]

10. Kämpfer, P.; Glaeser, S.P.; Parkes, L.; van Keulen, G.; Dyson, P. The Family Streptomycetaceae. In The Prokaryotes: Actinobacteria; Rosenberg, E., DeLong, E.F., Lory, S., Stackebrandt, E., Thompson, F., Eds.; Springer: Berlin/Heidelberg, Germany, 2014; pp. 889-1010. [CrossRef]

11. Law, J.W.-F.; Chan, K.-G.; He, Y.-W.; Khan, T.M.; Ab Mutalib, N.-S.; Goh, B.-H.; Lee, L.-H. Diversity of Streptomyces Spp. from Mangrove Forest of Sarawak (Malaysia) and Screening of Their Antioxidant and Cytotoxic Activities. Sci. Rep. $2019,9,15262$. [CrossRef] [PubMed]

12. Sayed, A.M.; Hassan, M.H.A.; Alhadrami, H.A.; Hassan, H.M.; Goodfellow, M.; Rateb, M.E. Extreme Environments: Microbiology Leading to Specialized Metabolites. J. Appl. Microbiol. 2019, 128, 630-657. [CrossRef] [PubMed]

13. Slovenská Agentúra Životného Prostredia. Správa o Stave Životného Prostredia Slovenskej Republiky v Roku 2019.2019. Available online: https://www.enviroportal.sk/spravy/detail/10661 (accessed on 10 June 2021).

14. Fargašová, A. Znečistenie Kovmi na Slovensku. Štátny Geologický Ústav Dionýza Štúra, Bratislava. 2010. Available online: https: / / docplayer.cz/39517320-Znecistenie-kovmi-na-slovensku-2009.html (accessed on 10 June 2021).

15. Kučerová, G.; Majzlan, J.; Lalinská-Voleková, B.; Radková, A.; Bačík, P.; Michňová, J.; Šottník, P.; Jurkovič, L.; Klimko, T.; Steininger, R.; et al. Mineralogy of Neutral Mine Drainage in the Tailings of Siderite-Cu Ores in Eastern Slovakia. Can. Miner. 2014, 52, 779-798. [CrossRef]

16. Tóth, R.; Škultétyová, S.; Hiller, E.; Jurkovič, L'; Šottník, P.; Jaroslav, V.; Tatarková, V. Mobility of Potentially Toxic Elements in Sediments of the Tailings Impoundment Slovinky and Their Transport into the Surrounding Environment; Burkhard, J., Černík, M., Halousková, O., Eds.; Vodní Zdroje Ekomonitor Spol. s r.o: Chrudim, Czech Republic, 2013.

17. Takac, P.; Kozakova, L.; Valkova, M.; Zelenak, F. Heavy Metals in Soils in Middle Spiš. Acta Montan. Slovaca $2008,13,82-86$.

18. Belaňová, E. Monitoring of Qualitative State of Soils in Hnúšt'a. ACTA Fac. Ecol. 2015, 33, 5-13.

19. Baroniaková, K. Streptomycéty z Prostredí Kontaminovaných Ťažkými Kovmi-Genetická a Biologická Charakterizácia, Košice. 2018. Available online: https:/ / opac.crzp.sk/?fn=detailBiblioForm\&sid=BCB1C6D618A1774C85DFCD5E7FBF (accessed on 10 June 2021). 
20. Porter, J.N.; Wilhelm, J.J.; Tresner, H.D. Method for the Preferential Isolation of Actinomycetes from Soils. Appl. Microbiol. 1960, 8 , 174-178. [CrossRef] [PubMed]

21. Shepherd, M.D.; Kharel, M.K.; Bosserman, M.A.; Rohr, J. Laboratory Maintenance of Streptomyces Species. Curr. Protoc. Microbiol. 2010, 18, 1-10. [CrossRef]

22. Tresner, H.D.; Backus, E.J. System of Color Wheels for Streptomycete Taxonomy. Appl. Microbiol. 1963, 11, 335-338. [CrossRef]

23. Hasan, F.; Shah, A.A.; Hameed, A. Methods for Detection and Characterization of Lipases: A Comprehensive Review. Biotechnol. Adv. 2009, 27, 782-798. [CrossRef] [PubMed]

24. Rahman, M.S.; Banu, R.; Moni, R.; Islam, N.; Ruma, M.K.; Zohora, U.S. Investigation on a Bangladeshi Isolate Bacillus Aryabhattai for Promising Biotechnological Applications. Jahangirnagar Univ. J. Biol. Sci. 2018, 7, 33-45. [CrossRef]

25. Sakthivel, M.; Karthikeyan, N.; Jayaveny, R.; Palani, P. Optimization of Culture Conditions for the Production of Extracellular Cellulase from Corynebacterium Lipophiloflavum. J. Ecobiotechnol. 2010, 2, 6-13.

26. Nybo, S.E.; Shepherd, M.D.; Bosserman, M.A.; Rohr, J. Genetic Manipulation of Streptomyces Species. Curr. Protoc. Microbiol. 2010, 19, 1-26. [CrossRef]

27. Weisburg, W.G.; Barns, S.M.; Pelletier, D.A.; Lane, D.J. 16S Ribosomal DNA Amplification for Phylogenetic Study. J. Bacteriol. 1991, 173, 697-703. [CrossRef]

28. Vandžurová, A.; Bačkor, P.; Javorský, P.; Pristaš, P. Staphylococcus Nepalensis in the Guano of Bats (Mammalia). Vet. Microbiol. 2013, 164, 116-121. [CrossRef]

29. Kumar, S.; Stecher, G.; Li, M.; Knyaz, C.; Tamura, K. MEGA X: Molecular Evolutionary Genetics Analysis across Computing Platforms. Mol. Biol. Evol. 2018, 35, 1547-1549. [CrossRef] [PubMed]

30. Zhang, Z.; Schwartz, S.; Wagner, L.; Miller, W. A Greedy Algorithm for Aligning DNA Sequences. J. Comput. Biol. 2000, 7, 203-214. [CrossRef] [PubMed]

31. Rong, X.; Huang, Y. Taxonomic Evaluation of the Streptomyces Griseus Clade Using Multilocus Sequence Analysis and DNADNA Hybridization, with Proposal to Combine 29 Species and Three Subspecies as 11 Genomic Species. Int. J. Syst. Evol. Microbiol. 2010, 60, 696-703. [CrossRef] [PubMed]

32. El Baz, S.; Baz, M.; Barakate, M.; Hassani, L.; El Gharmali, A.; Imziln, B. Resistance to and Accumulation of Heavy Metals by Actinobacteria Isolated from Abandoned Mining Areas. Sci. World J. 2015, 2015, 761834. [CrossRef] [PubMed]

33. Edgar, R.C. Updating the 97\% Identity Threshold for 16S Ribosomal RNA OTUs. Bioinformatics 2018, 34, 2371-2375. [CrossRef]

34. Mohammadipanah, F.; Hamedi, J.; Spröer, C.; Rohde, M.; del Carmen Montero-Calasanz, M.; Klenk, H.-P. Streptomyces Zagrosensis Sp. Nov., Isolated from Soil. Int. J. Syst. Evol. Microbiol. 2014, 64, 3434-3440. [CrossRef]

35. Rong, X.; Guo, Y.; Huang, Y. Proposal to Reclassify the Streptomyces Albidoflavus Clade on the Basis of Multilocus Sequence Analysis and DNA-DNA Hybridization, and Taxonomic Elucidation of Streptomyces Griseus Subsp. Solvifaciens. Syst. Appl. Microbiol. 2009, 32, 314-322. [CrossRef]

36. Kim, K.-O.; Shin, K.-S.; Kim, M.N.; Shin, K.-S.; Labeda, D.P.; Han, J.-H.; Kim, S.B. Reassessment of the Status of Streptomyces Setonii and Reclassification of Streptomyces Fimicarius as a Later Synonym of Streptomyces Setonii and Streptomyces Albovinaceus as a Later Synonym of Streptomyces Globisporus Based on Combined 16S RRNA/GyrB Gene Sequence Analysis. Int. J. Syst. Evol. Microbiol. 2012, 62, 2978-2985. [CrossRef]

37. Liu, Z.; Shi, Y.; Zhang, Y.; Zhou, Z.; Lu, Z.; Li, W.; Huang, Y.; Rodríguez, C.; Goodfellow, M. Classification of Streptomyces Griseus (Krainsky 1914) Waksman and Henrici 1948 and Related Species and the Transfer of 'Microstreptospora Cinerea' to the Genus Streptomyces as Streptomyces Yanii Sp. Nov. Int. J. Syst. Evol. Microbiol. 2005, 55, 1605-1610. [CrossRef] [PubMed]

38. Komaki, H.; Tamura, T. Reclassification of Streptomyces Fulvissimus as a Later Heterotypic Synonym of Streptomyces Microflavus. Int. J. Syst. Evol. Microbiol. 2020, 70, 5156-5162. [CrossRef]

39. Saitou, N.; Nei, M. The Neighbor-Joining Method: A New Method for Reconstructing Phylogenetic Trees. Mol. Biol. Evol. 1987, 4, 406-425. [CrossRef] [PubMed]

40. Felsenstein, J. Confidence Limits on Phylogenies: An Approach Using the Bootstrap. Evolution 1985, 39, 783-791. [CrossRef] [PubMed]

41. Kimura, M. A Simple Method for Estimating Evolutionary Rate of Base Substitutions through Comparative Studies of Nucleotide Sequences. J. Mol. Evol. 1980, 16, 111-120. [CrossRef] [PubMed]

42. Duxbury, T. Toxicity of Heavy Metals to Soil Bacteria. FEMS Microbiol. Lett. 1981, 11, 217-220. [CrossRef]

43. Pristas, P.; Stramova, Z.; Kvasnova, S.; Judova, J.; Perhacova, Z.; Vidova, B.; Sramkova, Z.; Godany, A. Non-Ferrous Metal Industry Waste Disposal Sites As A Source of Poly-Extremotolerant Bacteria. In Nova Biotechnologica et Chimica; Walter de Gruyter GmbH: Berlin, Germany, 2015; Volume 14, pp. 62-68. [CrossRef]

44. Michaeli, E.; Boltižiar, M.; Solár, V.; Vilček, J.; Ivanová, M. Landfill Waste from the Production of Nickel and Cobalt in the Slovak Republic. Int. J. Metall. Mater. Eng. 2016, 2, 126. [CrossRef]

45. Michaeli, E.; Solár, V.; Maxin, M.; Vilček, J.; Boltižiar, M. The Nature of the Technosols on the Waste from Nickel Production. Sustainability 2021, 13, 406. [CrossRef]

46. Karelová, E.; Harichová, J.; Stojnev, T.; Pangallo, D.; Ferianc, P. The Isolation of Heavy-Metal Resistant Culturable Bacteria and Resistance Determinants from a Heavy-Metal-Contaminated Site. Biologia 2011, 66, 18-26. [CrossRef] 
47. Sedlakova-Kadukova, J.; Kopcakova, A.; Gresakova, L.; Godany, A.; Pristas, P. Bioaccumulation and Biosorption of Zinc by a Novel Streptomyces K11 Strain Isolated from Highly Alkaline Aluminium Brown Mud Disposal Site. Ecotoxicol. Environ. Saf. 2019, 167, 204-211. [CrossRef]

48. Polti, M.A.; Amoroso, M.J.; Abate, C.M. Chromium(VI) Resistance and Removal by Actinomycete Strains Isolated from Sediments. Chemosphere 2007, 67, 660-667. [CrossRef]

49. Albarracín, V.H.; Amoroso, M.J.; Abate, C.M. Isolation and Characterization of Indigenous Copper-Resistant Actinomycete Strains. Geochemistry 2005, 65, 145-156. [CrossRef]

50. Albarracín, V.H.; Ávila, A.L.; Amoroso, M.J.; Abate, C.M. Copper Removal Ability by Streptomyces Strains with Dissimilar Growth Patterns and Endowed with Cupric Reductase Activity. FEMS Microbiol. Lett. 2008, 288, 141-148. [CrossRef] [PubMed]

51. Siñeriz, M.L.; Kothe, E.; Abate, C.M. Cadmium Biosorption by Streptomyces Sp. F4 Isolated from Former Uranium Mine. J. Basic Microbiol. 2009, 49, 55-62. [CrossRef] [PubMed]

52. Rho, J.-Y.; Kim, J.-H. Heavy Metal Biosorption and Its Significance to Metal Tolerance of Streptomycetes. J. Microbiol. 2002, 40, $51-54$.

53. Amoroso, M.J.; Castro, G.R.; Durán, A.; Peraud, O.; Oliver, G.; Hill, R.T. Chromium Accumulation by Two Streptomyces Spp. Isolated from Riverine Sediments. J. Ind. Microbiol. Biotechnol. 2001, 26, 210-215. [CrossRef] [PubMed]

54. Ravel, J.; Amoroso, M.J.; Colwell, R.R.; Hill, R.T. Mercury-Resistant Actinomycetes from the Chesapeake Bay. FEMS Microbiol. Lett. 1998, 162, 177-184. [CrossRef] [PubMed]

55. Van Nostrand, J.D.; Khijniak, T.V.; Gentry, T.J.; Novak, M.T.; Sowder, A.G.; Zhou, J.Z.; Bertsch, P.M.; Morris, P.J. Isolation and Characterization of Four Gram-Positive Nickel-Tolerant Microorganisms from Contaminated Sediments. Microb. Ecol. 2007, 53, 670-682. [CrossRef] [PubMed]

56. Majzlik, P.; Strasky, A.; Adam, V.; Nemec, M.; Trnkova, L.; Zehnalek, J.; Hubalek, J.; Provaznik, I.; Kizek, R. Influence of Zinc(II) and Copper(II) Ions on Streptomyces Bacteria Revealed by Electrochemistry. Int. J. Electrochem. Sci. 2011, 6, $2171-2191$.

57. Schmidt, A.; Schmidt, A.; Haferburg, G.; Kothe, E. Superoxide Dismutases of Heavy Metal Resistant Streptomycetes. J. Basic Microbiol. 2007, 47, 56-62. [CrossRef]

58. Schmidt, A.; Haferburg, G.; Sineriz, M.; Merten, D.; Büchel, G.; Kothe, E. Heavy Metal Resistance Mechanisms in Actinobacteria for Survival in AMD Contaminated Soils. Geochemistry 2005, 65, 131-144. [CrossRef]

59. Schmidt, A.; Haferburg, G.; Schmidt, A.; Lischke, U.; Merten, D.; Ghergel, F.; Büchel, G.; Kothe, E. Heavy Metal Resistance to the Extreme: Streptomyces Strains from a Former Uranium Mining Area. Geochemistry 2009, 69, 35-44. [CrossRef]

60. Guo, J.K.; Lin, Y.B.; Zhao, M.L.; Sun, R.; Wang, T.T.; Tang, M.; Wei, G.H. Streptomyces Plumbiresistens Sp. Nov., a Lead-Resistant Actinomycete Isolated from Lead-Polluted Soil in North-West China. Int. J. Syst. Evol. Microbiol. 2009, 59, 1326-1330. [CrossRef]

61. Lin, Y.B.; Wang, X.Y.; Li, H.F.; Wang, N.N.; Wang, H.X.; Tang, M.; Wei, G.-H. Streptomyces Zinciresistens Sp. Nov., a Zinc-Resistant Actinomycete Isolated from Soil from a Copper and Zinc Mine. Int. J. Syst. Evol. Microbiol. 2011, 61, 616-620. [CrossRef] [PubMed]

62. Desjardin, V.; Bayard, R.; Huck, N.; Manceau, A.; Gourdon, R. Effect of Microbial Activity on the Mobility of Chromium in Soils Waste Manag. 2002, 22, 195-200. [CrossRef]

63. Dávila Costa, J.S.; Hoskisson, P.A.; Paterlini, P.; Romero, C.M.; Alvarez, A. Whole Genome Sequence of the Multi-Resistant Plant Growth-Promoting Bacteria Streptomyces Sp. Z38 with Potential Application in Agroindustry and Bio-Nanotechnology. Genomics 2020, 112, 4684-4689. [CrossRef] [PubMed]

64. Simón Solá, M.Z.; Lovaisa, N.; Dávila Costa, J.S.; Benimeli, C.S.; Polti, M.A.; Alvarez, A. Multi-Resistant Plant Growth-Promoting Actinobacteria and Plant Root Exudates Influence Cr(VI) and Lindane Dissipation. Chemosphere 2019, 222, 679-687. [CrossRef]

65. Undabarrena, A.; Ugalde, J.A.; Seeger, M.; Cámara, B. Genomic Data Mining of the Marine Actinobacteria Streptomyces Sp. H-KF8 Unveils Insights into Multi-Stress Related Genes and Metabolic Pathways Involved in Antimicrobial Synthesis. Peer J. 2017, 5 , 1-35. [CrossRef]

66. Undabarrena, A.; Beltrametti, F.; Claverías, F.P.; González, M.; Moore, E.R.B.; Seeger, M.; Cámara, B. Exploring the Diversity and Antimicrobial Potential of Marine Actinobacteria from the Comau Fjord in Northern Patagonia, Chile. Front. Microbiol. $2016,7$. [CrossRef] [PubMed]

67. Li, X.; Ding, C.; Liao, J.; Du, L.; Sun, Q.; Yang, J.; Yang, Y.; Zhang, D.; Tang, J.; Liu, N. Bioaccumulation Characterization of Uranium by a Novel Streptomyces Sporoverrucosus Dwc-3. J. Environ. Sci. 2016, 41, 162-171. [CrossRef]

68. Tang, X.; Zhao, J.; Li, K.; Chen, Z.; Sun, Y.; Gao, J. Streptomyces Cyaneochromogenes Sp. Nov., a Blue Pigment-Producing Actinomycete from Manganese-Contaminated Soil. Int. J. Syst. Evol. Microbiol. 2019, 69, 2202-2207. [CrossRef] [PubMed]

69. Zhou, G.; Yang, H.; Zhou, H.; Wang, C.; Fu, F.; Yu, Y.; Lu, X.; Tian, Y. Complete Genome Sequence of the Streptomyces Sp. Strain CdTB01, a Bacterium Tolerant to Cadmium. J. Biotechnol. 2016, 229, 42-43. [CrossRef] [PubMed]

70. Mo, P.; Zhao, J.; Li, K.; Tang, X.; Gao, J. Streptomyces Manganisoli Sp. Nov., a Novel Actinomycete Isolated from ManganeseContaminated Soil. Int. J. Syst. Evol. Microbiol. 2018, 68, 1890-1895. [CrossRef] [PubMed]

71. Li, K.; Tang, X.; Zhao, J.; Guo, Y.; Tang, Y.; Gao, J. Streptomyces Cadmiisoli Sp. Nov., a Novel Actinomycete Isolated from Cadmium-Contaminated Soil. Int. J. Syst. Evol. Microbiol. 2019, 69, 1024-1029. [CrossRef]

72. Mo, P.; Yu, Y.-Z.; Zhao, J.-R.; Gao, J. Streptomyces Xiangtanensis Sp. Nov., Isolated from a Manganese-Contaminated Soil. Antonie Leeuwenhoek 2017, 110, 297-304. [CrossRef]

73. Li, H.; Lin, Y.; Guan, W.; Chang, J.; Xu, L.; Guo, J.; Wei, G. Biosorption of Zn(II) by Live and Dead Cells of Streptomyces Ciscaucasicus Strain CCNWHX 72-14. J. Hazard. Mater. 2010, 179, 151-159. [CrossRef] 
74. Lin, Y.; Wang, X.; Wang, B.; Mohamad, O.; Wei, G. Bioaccumulation Characterization of Zinc and Cadmium by Streptomyces Zinciresistens, a Novel Actinomycete. Ecotoxicol. Environ. Saf. 2012, 77, 7-17. [CrossRef]

75. Sanjenbam, P.; Saurav, K.; Kannabiran, K. Biosorption of Mercury and Lead by Aqueous Streptomyces VITSVK9 Sp. Isolated from Marine Sediments from the Bay of Bengal, India. Front. Chem. Sci. Eng. 2012, 6, 198-202. [CrossRef]

76. Qin, S.; Li, W.-J.; Dastager, S.G.; Hozzein, W.N. Editorial: Actinobacteria in Special and Extreme Habitats: Diversity, Function Roles, and Environmental Adaptations. Front. Microbiol. 2016, 7, 6-7. [CrossRef]

77. Labeda, D.P.; Goodfellow, M.; Brown, R.; Ward, A.C.; Lanoot, B.; Vanncanneyt, M.; Swings, J.; Kim, S.-B.; Liu, Z.; Chun, J.; et al. Phylogenetic Study of the Species within the Family Streptomycetaceae. Antonie Leeuwenhoek 2012, 101, 73-104. [CrossRef]

78. Antony-Babu, S.; Stien, D.; Eparvier, V.; Parrot, D.; Tomasi, S.; Suzuki, M.T. Multiple Streptomyces Species with Distinct Secondary Metabolomes Have Identical 16S RRNA Gene Sequences. Sci. Rep. 2017, 7. [CrossRef]

79. Labeda, D.P. Crossiella Gen. Nov., a New Genus Related to Streptoalloteichus. Int. J. Syst. Evol. Microbiol. 2001, 51, 1575-1579. [CrossRef] [PubMed] 